\title{
Detection of CTX-M gene in extended spectrum $\beta$-lactamases producing Enterobacteriaceae isolated from bovine milk
}

\author{
I.M. Ahmed \\ Department of Microbiology, College of Veterinary Medicine, University of Mosul, Mosul, Iraq
}

Article information

\section{Article history:}

Received April 9, 2020

Accepted May 14, 2020

Available online March 15, 2021

\section{Keywords:}

Milk

PCR

Enterobacteriaceae

ESBL-E

CTX-M

Correspondence:

I.M. Ahmed

ihsanahmad1@yahoo.com

\begin{abstract}
Extended spectrum $\beta$-lactamases producing Enterobacteriaceae (ESBL-E) have emerged recently as the main cause that facilitates the spreading of antibiotic resistance worldwide. Due to its composition and nutritive values, raw cow milk is vulnerable to bacterial contamination from different sources, especially ESBL-E. Accordingly, present study aimed to detect the ESBL- $E$ in the raw milk of healthy cows. 80 raw cow milk samples were collected from unorganized farms and cows belong to individual owners and investigated for the presence of ESBL- $E$ with the main focusing on CTX-M type. The bacterial isolation was performed using selective MacConkey agar plus cefotaxime $\left(\mathrm{MC}^{+}\right)$, while PCR was used to confirm the species of the isolated bacteria and presence of CTX-M gene. The results showed that $28.75 \%(23 / 80)$ samples were ESBL-E positive and distributed as following, $82.61 \%(19 / 23)$ were pure $E$. coli isolates, $4.35 \%(1 / 23)$ was pure $K$. pneumoniae isolate and finally, $13.04 \%(3 / 23)$ were mixed of both $E$. coli and $K$. pneumoniae isolates. Moreover, the total number of positive ESBL- $E$ was 26 isolates with the majority of them were belong to $E$. coli and recorded $84.61 \%(22 / 26)$, while $K$. pneumoniae was recorded less $15.39 \%(4 / 26)$. Additionally, the CTX-M gene was successfully identified in all ESBL- $E$ positive isolates by using PCR, including E. coli and $K$. pneumoniae isolates. The results of this study assert the importance of raw cow milk as a potential source of ESBL- $E$ that might be transmitted to humans.
\end{abstract}

DOI: $10.33899 /$ ijvs.2020.126909.1412, (C2021, College of Veterinary Medicine, University of Mosul.

This is an open access article under the CC BY 4.0 license (http://creativecommons.org/licenses/by/4.0/).

\section{Introduction}

Bovine milk is considered a major source of proteins and vitamins for humans, in addition to providing energy. It is beneficial for early life and aged people due to its complete nutritional components (1). However, in many developing countries, the misuse of antibiotics in veterinary medicine and animal husbandry, especially as subtheraputics and growth promoters, leads to development of antimicrobial resistance especially in milk and dairy products (2). Globally, drug-resistant microorganisms have become an increasingly important health problem in man and animals which results in a reduction in the efficacy of many common antibiotics $(3,4)$. During the last decades, extended-spectrum B-lactamases (ESBLs) have been globally increased. They have considered as a main source of Gram-negative bacterial pathogens that have the resistance feature to the most important antibiotics especially Escherichia coli, Klebsiella pneumoniae and Proteus mirabilis as main members of Enterobacteriaceae $(3,5,6)$. However, close contact with animals and consuming of their products is considered as a risk factor that might have a role in transferring of positive ESBL bacteria to humans, especially with the dramatic increase of commensal ESBL (3-5,7). ESBLs have the ability to hydrolyse different types of cephalosporins including, cefotaxime, ceftazidime, ceftriaxone, and cefepime $(8,9)$. The main detected type of ESBL is CTX-M $\beta$-lactamase rather than other $\beta$-lactamases including classical TEM- and SHV-types of ESBLs. It has been reported worldwide in both human and animal populations 
$(6,8)$. In recent years, there were enormous increased of documentations that related to CTX-M-type of ESBLs produced by different members of the Enterobacteriaceae $(7,10)$, and this highlighted the importance of this gene among antibiotic resistance Enterobacteriaceae that could transfer the resistance to other bacteria especially gut pathogens (3). Moreover, the ESBL has frequently encoded by plasmids. Yet, plasmids including ESBL may also carry other different types of antibiotic resistance genes, which make the options of treatment very limited for ESBL producing bacteria (7). In Iraq, many studies have been carried out related to the detection of ESBL mainly in humans $(11,12)$. However, Al-Sharook and Hassan (13) referred to successful isolation of ESBL $E$. coli in broilers. Little is known about the presence of ESBL Enterobacteriaceae in bovine milk. Therefore, the presence of ESBL Enterobacteriaceae especially from milk of healthy cows is a fact that has to be addressed properly. Accordingly, this study was aimed to detect the presence of CTX-M gene in ESBL- $E$ from raw cow milk as a potential marker that indicates for the presence of antibiotic resistance.

\section{Materials and methods}

\section{Samples collection}

Eighty samples of raw cow milk were collected randomly from unorganized smallholder dairy farms or individual owners in Mosul city, during the period of April to August 2019. Approximately, $30 \mathrm{ml}$ volume of raw milk was collected aseptically from apparently healthy lactating cows in a sterile disposable container and transported using cooling box to Microbiology Laboratory-Department of Microbiology at College of Veterinary Medicine-University of Mosul. The samples were kept cooled at $4^{\circ} \mathrm{C}$ until being further process.

\section{Bacterial isolation and identification}

A volume of $10 \mathrm{ml}$ of milk samples was centrifuged at $3000 \times g$ for $20 \mathrm{~min}$. Then the supernatant was removed and the pellet was mixed with $100 \mu \mathrm{l}$ of sterile $0.9 \% \mathrm{NaCl}$ solution and cultured on specially prepared selective MacConkey agar plus antibiotic cefotaxime $\left(\mathrm{MC}^{+}\right)$(Foxime $500 \mathrm{mg}$, Tabuk, KSA) at a final concentration $1 \mu \mathrm{g} / \mathrm{ml}$ according to Ali et al. (14). This medium has the ability to select the bacteria that resist cefotaxime. The cultured plates were put in the incubator at $37^{\circ} \mathrm{C}$ for $24 \mathrm{~h}$. All ESBL-positive colonies were subsequently determined and subsequently subcultured on Brain Heart Infusion agar (Lab M, UK) for further bacterial identification using standard bacteriological methods, including Gram staining and biochemical tests (15).

\section{Extraction of DNA}

Selected colonies were picked depending on their growth ability on $\mathrm{MC}^{+}$agar and subsequent phenotypic identification, only E. coli and K. pneumoniae colonies were successfully identified as members of Enterobacteriaceae that showed ESBL activity. Accordingly, only ESBL positive colonies that have been isolated on $\mathrm{MC}^{+}$were subjected to DNA extraction using Bacteria DNA Preparation Kit (Jena Bioscience, Germany). Following the manufacturer instructions with slight modification, fresh overnight cultures on Brain Heart Infusion agar (Lab M, UK) were used, and few colonies were transferred into a sterile $1.5 \mathrm{ml}$ microcentrifuge tube, which previously contains 300 $\mu \mathrm{l}$ of Cell Lysis Solution followed by adding $1.5 \mu$ l of RNase A Solution and mixed gently by several inverting, then the microcentrifuge was put in the incubator at $37^{\circ} \mathrm{C}$ for $30 \mathrm{~min}$ followed by cooling on ice for $1 \mathrm{~min}$ to precipitate the proteins. Then, $100 \mu \mathrm{l}$ of Protein Precipitation Solution was added to each tube and mixed vigorously by vortex for 20 $30 \mathrm{sec}$, then centrifuged at $15,000 \mathrm{xg}$ for $5 \mathrm{~min}$. The DNA was precipitated by transferring the supernatant to a new clean $1.5 \mathrm{ml}$ microcentrifuge with previously added $300 \mu \mathrm{l}$ Isopropanol with concentration of $99 \%$ and mixed by gentle inverting for $1 \mathrm{~min}$. The DNA was pellet down by centrifugation at $15,000 \mathrm{xg}$ for $1 \mathrm{~min}$. The supernatant was removed out and the microcentrifuge was drained. The DNA pellet was washed by adding $500 \mu$ of Washing Buffer followed by inverting the tube several times and centrifuged at $15,000 \times \mathrm{x}$ for $1 \mathrm{~min}$ and the Washing Buffer was removed carefully. The microcentrifuge was dried at ambiante temperature for $20 \mathrm{~min}$ and the DNA was hydrated by adding $100 \mu$ of DNA Hydration Solution to the previously dried DNA pellet and incubated in water bath at $65^{\circ} \mathrm{C}$ for $60 \mathrm{~min}$. After hydration the DNA was kept at $-20^{\circ} \mathrm{C}$ for subsequent assay.

\section{Polymerase chain reaction (PCR)}

PCR was performed to confirm these bacteria using species-specific primers (E. coli: ECO223-F and ECO 455$\mathrm{R} ;$ K. pneumoniae: SSKP $1 \mathrm{~F}$ and SSKP $1 \mathrm{R}$ (Table 1). The PCR cocktail mixtures were prepared in $20 \mu \mathrm{l}$ containing 10 $\mu 1$ HS Prime Taq Premix (2X) (GeNet Bio, Korea), $1 \mu 1$ of each primer $10 \mathrm{mmol}$ (IDT, USA), $2 \mu \mathrm{l}$ of DNA template final concentration $(2 \mathrm{ng} / \mu \mathrm{l})$ and $6 \mu \mathrm{l}$ of PCR grade water. The PCR was done using the thermal cycler (BioRad, T100, Bio-Rad, USA). The cycling conditions include 1 cycle of initial denaturation at $94^{\circ} \mathrm{C}$ for $10 \mathrm{~min}, 35$ cycles consisting of (initial denaturation at $94^{\circ} \mathrm{C}$ for $30 \mathrm{sec}$, annealing at $\left(55^{\circ} \mathrm{C}\right.$ for E. coli and $57^{\circ} \mathrm{C}$ for $K$. pneumoniae) for $30 \mathrm{sec}$ and extension at $72^{\circ} \mathrm{C}$ for $45 \mathrm{sec}$ ). Then, one cycle of final extension at $72^{\circ} \mathrm{C}$ for $5 \mathrm{~min}$. Finally, the reaction was holed for cooling at $4^{\circ} \mathrm{C}$ for the next step of gel electrophoresis. Additional PCR was performed to confirm the presence of (CTX-M) using specific primers (CTX-M-Uni-F and CTXM-Uni-R) Table 1. using the same PCR reaction and cycling conditions, except the annealing temperature that set at $54^{\circ} \mathrm{C}$. The amplified products were separated using the agarose gel electrophoresis in $1.2 \%$ agarose gel (Promega, USA) 
containing Prime Safe Dye (GeNet Bio, Korea). A volume of $5 \mu \mathrm{l}$ of each PCR product was loaded into the well of agarose gel. The electrophoresis was carried out at $80 \mathrm{~V}, 300 \mathrm{~mA}$ for 1 hour using Wide Mini-Sub Cell GT gel electrophoresis systems and power supply (Bio-Rad, USA) containing $1 \mathrm{X}$
TBE buffer (Bio-Rad, USA). A 100 bp DNA marker, $4 \mu 1$ (GeNet Bio, Korea) was used as standard molecular weight marker. After electrophoresis, the gel was viewed using Gel doc Ez system (Bio-Rad-USA) to detect the specific bands.

Table 1: Sequences of primers used for PCR

\begin{tabular}{|c|c|c|c|c|c|c|}
\hline No. & Primer Name & Primer Sequence 5' - 3' & Target gene & Annealing Temp ${ }^{\circ} \mathrm{C}$ & size bp & Ref. \\
\hline 1 & ECO223-F & ATCAACCGAGATTCCCCCAGT & \multirow{2}{*}{ 16SrRNA } & \multirow{2}{*}{55} & \multirow{2}{*}{232} & \multirow{2}{*}{ (16) } \\
\hline 2 & ECO 455-R & TCACTATCGGTCAGTCAGGAG & & & & \\
\hline 3 & SSKP $1 \mathrm{~F}$ & ATTTGAAGAGGTTGCAAACGAT & \multirow{2}{*}{ 16SrRNA } & \multirow{2}{*}{57} & \multirow{2}{*}{130} & \multirow{2}{*}{ (17) } \\
\hline 4 & SSKP $1 \mathrm{R}$ & TTCACTCTGAAGTTTTCTTGTGTTC & & & & \\
\hline 5 & CTX-M-Uni-F & CGCTTTGCGATGTGCAG & \multirow{2}{*}{${ }^{b l a} \mathrm{CTX}-\mathrm{M}$} & \multirow{2}{*}{54} & \multirow{2}{*}{550} & \multirow{2}{*}{ (14) } \\
\hline 6 & CTX-M-Uni-R & ACCGCGATATCGTTGGT & & & & \\
\hline
\end{tabular}

\section{Results}

The results of bacterial isolation on $\mathrm{MC}^{+}$and subsequent phenotypic identification methods showed that $28.75 \%$ (23/80) of raw cow milk samples were positive for ESBL-E as following. $82.61 \%(19 / 23)$ with pure E. coli isolates, $4.35 \%(1 / 23)$ with pure $K$. pneumoniae isolate and $13.04 \%$ $(3 / 23)$ with mixed isolates of both $E$. coli and $K$. pneumoniae isolates. Furthermore, a total of 26 ESBL- $E$ bacterial isolates were successfully obtained from these 23 samples and $E$. coli was dominated and recorded $84.61 \%(22 / 26)$, while $K$. pneumoniae was recorded less $15.39 \%$ (4/26). Furthermore, the results of PCR revealed the presence of expected band size at $232 \mathrm{bp}$ and $130 \mathrm{bp}$, for $E$. coli (Figure 1) and $K$. pneumoniae (Figure 2), respectively. A further molecular investigation was done to detect the occurrence of CTX-M gene among the positive ESBL isolates. The results showed that all the tested isolates were confirmed positive for CTX$\mathrm{M}$ gene (Figure 3).

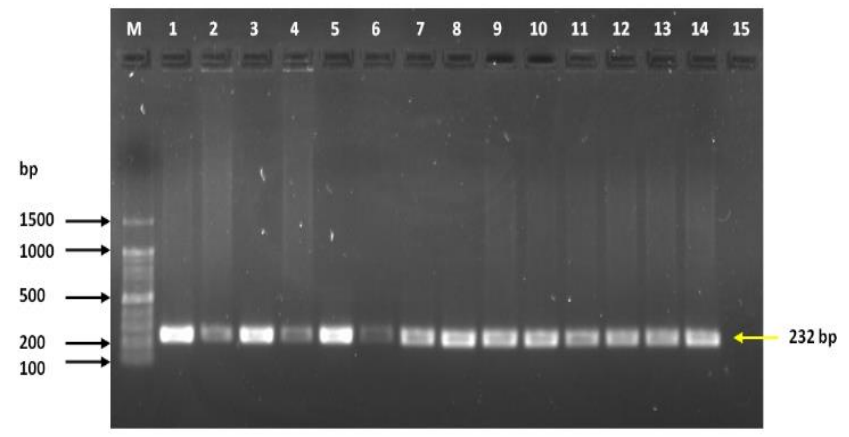

Figure 1: Represent gel electrophoresis of PCR final products of E. coli. Lane M, DNA marker (100 bp); lane 114 positive $E$. coli samples giving 232 bp product size; lane 15 , control negative.

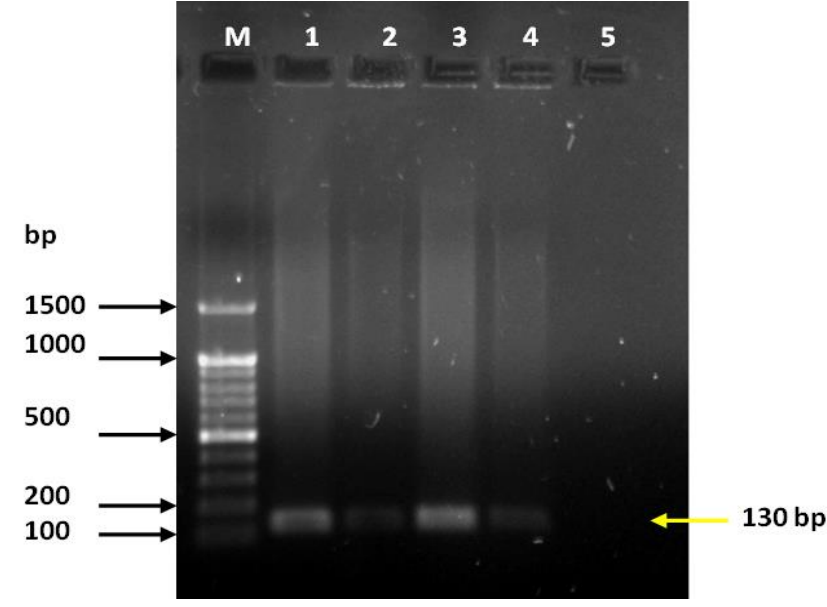

Figure 2: Represent gel electrophoresis of PCR final products of K. pneumoniae. Lane M, DNA marker (100 bp); lane 1-4 positive $K$. pneumoniae samples giving $130 \mathrm{bp}$ product size; lane 5, control negative.

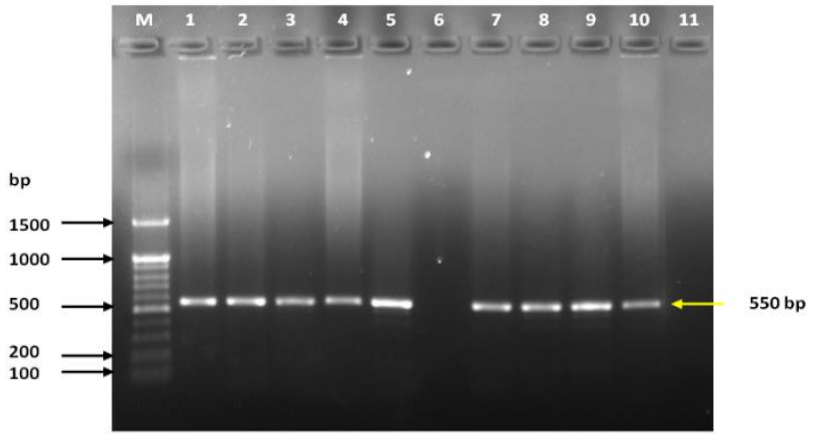

Figure 3: Represent gel electrophoresis of PCR final products of the CTX-M gene. Lane M, DNA marker (100 bp); lane 1-5 positive samples of CTX-M for E. coli giving 550 bp product size; lane 6 negative control, lane 7-10 positive samples of CTX-M for K. pneumoniae giving 550 bp product size; lane 11 control negative. 


\section{Discussion}

Increasing resistance to antibiotics became a global concern for both human and veterinary fields $(8,18-20)$. Members of Enterobacteriaceae have been involved in different cases of unresponsiveness to antibiotic treatment including human infections such as community-acquired and foodborne infections. In addition, unresponsive to treatment in animals, especially production diseases such as mastitis (21-24). In this study, 28.75\% (23/80) of raw milk samples were ESBL positive which belongs to apparently healthy cows. These results were higher compared with Batabyal et al. (5), who reported in his study in West Bengal that $12.1 \%$ (22/182) were ESBL E. coli positive from the collected milk samples which targeted organized dairy cow farms that appeared healthy. While Badri et al. (25) detect high positive ESBL- $E$ with dominant CTX-M type isolated from the raw cow milk with $29.3 \%$ and $44.8 \%$ for $E$. coli and $K$. pneumonia, respectively. The high increase of ESBL reflects the unhygienic conditions of milk handing and production in addition to the use of traditional systems for milk manufacturing and transportation that favour contamination by fecal Enterobacteriaceae $(4,26)$. However, Geser et al. (20) reported that no ESBL bacteria were found in milk obtained from bulk storage tank in Switzerland. The authors justify that due to the high quality based system adapted for processing tank milk. It is clear that organized dairy farms that follow strict hygienic rules and controlled use of antibiotics might develop less antibiotic resistance than the farming of few cows under uncontrolled regimes. The positive isolates of ESBL- $E$ were additionally identified using PCR as a molecular tool and E. coli and K. pneumoniae were confirmed. This step was necessary to confirm the species of isolated bacteria for the next step to detect CTX$M$ positive bacteria using molecular identification. The PCR results using species-specific primers for both $E$. coli and $K$. pneumoniae showed that the majority of isolated ESBL- $E$ was belonging to E. coli $84.61 \%$ while $K$. pneumoniae recorded $15.39 \%$. Many recent studies reported the implication of E. coli as a major source of ESBL in different circumstances $(23,24,27)$ and to less extend $K$. pneumoniae and other species of Enterobacteriaceae like Enterobacter spp., Serratia spp. and Citrobacter spp. $(8,28)$. Thus, the potential zoonoses and spreading of ESBL encoding bacteria between human and animals especially in farm workers are of great concern mainly in the developing countries (23). All the ESBL positive isolates on $\mathrm{MC}^{+}$were also showed a positive CTX-M gene in PCR. However other genes did not cover by this study such as SHV and TEM genes, and this might require further studies to investigate their roles. The choosing of CTX-M gene was due to its main role in antibiotics resistance among ESBLs $(4,8)$. The presence of CTX-M was reported in human $(18,29-31)$, in addition to different animal infections mainly related to bovine mastitis $(2,20,24)$. The proofing of ESBL- $E$ in raw cow milk in this study highlighted the concerns and risks about the increased probability of transmission of such resistant bacteria from non-diseased to diseased cows, especially those that might develop mastitis $(2,4,8)$. Finally, the continuous arbitrary using of the antibiotics in our human community and animal fields with the absence of standard hygienic methods for handling milk during processing and production, all could increase the risk of transmission and spreading of such ESBL- $E$ in both animals and humans.

\section{Conclusion}

In conclusion, CTX-M gene was successfully detected in ESBL- $E$ from raw cow milk which could be of a major risk for the spreading of antibiotic resistance. Future studies are needed to detect other types of resistance genes in dairy cows.

\section{Acknowledgments}

This study was supported by College of Veterinary Medicine, University of Mosul, Mosul, Iraq.

\section{Conflict of interest}

The author declare that he has no conflict of interest.

\section{References}

1. Poppitt SD. Milk proteins and human health. Milk Proteins: Elsevier; 2020. p. 651-69. eBook ISBN: 9780128152522

2. Tark D-S, Moon DC, Kang HY, Kim S-R, Nam H-M, Lee H-S, Jung S-C, Lim S-K. Antimicrobial susceptibility and characterization of extended-spectrum $\beta$-lactamases in Escherichia coli isolated from bovine mastitic milk in South Korea from 2012 to 2015. J Dairy Sci. 2017;100:3463-9. Doi: 10.3168/jds.2016-12276

3. Madec J-Y, Haenni M, Nordmann P, Poirel L. Extended-spectrum $\beta$ lactamase/AmpC-and carbapenemase-producing Enterobacteriaceae in animals: a threat for humans? Clin Microbiol Infect. 2017;23:82633. Doi: $10.1016 / \mathrm{j} . \mathrm{cmi} .2017 .01 .013$

4. Alonso C, Zarazaga M, Ben Sallem R, Jouini A, Ben Slama K, Torres C. Antibiotic resistance in Escherichia coli in husbandry animals: The African perspective. Lett Appl Microbiol. 2017;64:318-34. Doi: 10.1111/lam.12724

5. Batabyal K, Banerjee A, Pal S, Dey S, Joardar SN, Samanta I, Isore DP, Singh AD. Detection, characterization, and antibiogram of extendedspectrum beta-lactamase Escherichia coli isolated from bovine milk samples in West Bengal, India. Vet. World. 2018;11:1423. Doi: 10.14202.2Fvetworld.2018.1423-1427

6. Velasova M, Smith R, Lemma F, Horton RA, Duggett N, Evans J, Tongue S, Anjum MF, Randall L. Detection of extended-spectrum $\beta$ lactam, AmpC and carbapenem resistance in Enterobacteriaceae in beef cattle in Great Britain in 2015. J Appl Microbiol. 2019;126:108195. Doi: $10.1111 / \mathrm{jam} .14211$

7. Thenmozhi S, Moorthy K, Sureshkumar B, Suresh M. Antibiotic resistance mechanism of ESBL producing Enterobacteriaceae in clinical field: A review. Int. J. Pure App. Biosci.. 2014;2:207-26. [available here]

8. Palmeira JD, Ferreira HMN. Extended-spectrum beta-lactamase (ESBL)-producing Enterobacteriaceae in cattle production-a threat 
around the world. Heliyon. 2020;6:e03206. Doi: 10.1016/j.heliyon.2020.e03206

9. Lee S, Mir RA, Park SH, Kim D, Kim H-Y, Boughton RK, Morris Jr JG, Jeong KC. Prevalence of extended-spectrum $\beta$-lactamases in the local farm environment and livestock: challenges to mitigate antimicrobial resistance. Crit Rev Microbiol. 2020:1-14. Doi: 10.1080/1040841X.2020.1715339

10. Ohnishi M, Okatani AT, Harada K, Sawada T, Marumo K, Murakami M, Sato R, Esaki H, Shimura K, Kato H. Genetic characteristics of CTX-M-type extended-spectrum- $\beta$-lactamase (ESBL)-producing Enterobacteriaceae involved in mastitis cases on Japanese dairy farms, 2007 to 2011. J Clin Microbiol. 2013;51:3117-22. Doi: 10.1128/JCM.00920-13

11. Pishtiwan AH, Khadija KM. Prevalence of blaTEM, blaSHV, and blaCTX-M genes among ESBL-producing Klebsiella pneumoniae and Escherichia coli Isolated from thalassemia patients in Erbil, Iraq. Mediterranean J Hemato and Infec Dis. 2019, 11(1): e2019041. Doi: 10.4084/mjhid.2019.041

12. Polse RF, Yousif SY, Assafi MS. Prevalence and molecular characterization of extended spectrum beta-Lactamases-producing uropathogenic Escherichia coli isolated in Zakho, Iraq. J Microbio Infect Dis. 2016;6:163-7. Doi: 10.5799/ahinjs.02.2016.04.0237

13. Al-Sharook M, Hassan A. Isolation and identification of extendedspectrum beta-lactamase (ESBL)-producing Escherichia coli from broiler in Erbil, Iraq. Iraqi J Vet Sci. 2017;31:31-8. Doi: 10.33899/ijvs.2017.126717

14. Ali T, Zhang L, Shahid M, Zhang S, Liu G, Gao J, Han B. ESBLproducing Escherichia coli from cows suffering mastitis in China contain clinical class 1 integrons with CTX-M linked to ISCR1. Front. Microbio. 2016;7:1931. Doi: 10.3389/fmicb.2016.01931

15. Brooks G, Carroll K, Butel J, Morse S, Mietzner T. Jawetz, Melnick, Adelberg Medical Microbiology: Placebo doo; 2015. ISBN-13: 978-0 07-128735- 7.

16. Riffon R, Sayasith K, Khalil H, Dubreuil P, Drolet M, Lagacé J. Development of a rapid and sensitive test for identification of major pathogens in bovine mastitis by PCR. J Clin Microbiol. 2001;39:25849. Doi: 10.1128\%2FJCM.39.7.2584-2589.2001

17. Osman KM, Hassan HM, Orabi A, Abdelhafez AS. Phenotypic, antimicrobial susceptibility profile and virulence factors of Klebsiella pneumoniae isolated from buffalo and cow mastitic milk. Pathog Glob Health. 2014;108:191-9. Doi: 10.1179/2047773214Y.0000000141

18. Findlay J, Gould VC, North P, Bowker KE, Williams MO, MacGowan AP, Avison MB. Characterization of cefotaxime-resistant urinary Escherichia coli from primary care in South-West England 2017-18. J Antimicrob Chemother. 2020;75:65-71. Doi: 10.1093/jac/dkz397

19. Cormier AC, Chalmers G, Cook SR, Zaheer R, Hannon SJ, Booker CW, Read RR, Gow SP, McAllister TA, Boerlin P. Presence and Diversity of Extended-Spectrum Cephalosporin Resistance Among Escherichia coli from Urban Wastewater and Feedlot Cattle in Alberta, Canada. Microb Drug Resist. 2020;26:300-9. Doi: 10.1089/mdr.2019.0112

20. Geser N, Stephan R, Hächler H. Occurrence and characteristics of extended-spectrum $\beta$-lactamase (ESBL) producing Enterobacteriaceae in food producing animals, minced meat and raw milk. BMC Vet Res. 2012;8:21. [availabe here]

21. Ahmed, I. M., Al-Sanjary, R. A. and Al-Khazaly, H. H. Detection of Mycobacterium paratuberculosis in raw cow's milk using polymerase chain reaction (PCR) technique. Iraqi J Vet Sci. 2020;34(1):83-86. Doi: 10.33899/ijvs.2019.125556.1075

22. Soulieman, N., Al-Mariri, A., and Al-Atrash, F. Detection of Shigella in raw bovine milk by polymerase chain reaction. Iraqi $\mathrm{J}$ Vet Sci. 2020;34(1):9-16. Doi: 10.33899/ijvs.2019.125758.1146

23. Alegría Á, Arias-Temprano M, Fernández-Natal I, Rodríguez-Calleja JM, García-López M-L, Santos JA. Molecular Diversity of ESBLProducing Escherichia coli from Foods of Animal Origin and Human Patients. Int J Env Res Public Health. 2020;17:1312. Doi: 10.3390/ijerph17041312

24. Filioussis G, Kachrimanidou M, Christodoulopoulos G, Kyritsi M, Hadjichristodoulou C, Adamopoulou M, Tzivara A, Kritas SK, Grinberg A. Bovine mastitis caused by a multidrug-resistant, mcr-1- positive (colistin-resistant), extended-spectrum $\beta$-lactamase-producing Escherichia coli clone on a Greek dairy farm. J Dairy Sci. 2020;103:852-7. Doi: 10.3168/jds.2019-17320

25. Badri A, Ibrahim I, Mohamed S, Garbi M, Kabbashi A, Arbab M. Prevalence of extended spectrum beta lactamase (ESBL) producing Escherichia coli, and Klebsiella pneumoniae isolated from raw milk samples in Al Jazirah state, Sudan. Mol Biol. 2017;7:10-4172. Doi: 10.4172/2168-9547.1000201

26. Founou LL, Founou RC, Essack SY. Antibiotic resistance in the food chain: a developing country-perspective. Front. Microbiol. 2016;7:1881. Doi: $\underline{10.3389 / \text { fmicb.2016.01881 }}$

27. Zheng B, Feng C, Xu H, Yu X, Guo L, Jiang X, Song X. Detection and characterization of ESBL-producing Escherichia coli expressing mcr-1 from dairy cows in China. J Antimicrob Chemother. 2019;74:321-5. Doi: $\underline{10.1093 / \mathrm{jac} / \mathrm{dky} 446}$

28. Gaffer W, Gwida M, Samra RA, Al-Ashmawy M. Occurrence and molecular characterization of extended spectrum beta-lactamase producing Enterobacteriaceae in milk and some dairy products. Slovenian Veterinary Research. 2019;56. Doi: 10.26873/SVR-7852019

29. Melegh S, Schneider G, Horváth M, Jakab F, Emődy L, Tigyi Z. Identification and characterization of CTX-M-15 producing Klebsiella pneumoniae clone ST101 in a Hungarian university teaching hospital. Acta microbiologica et immunologica Hungarica. 2015;62:233-45. Doi: 10.1556/030.62.2015.3.2

30. Yasir M, Farman M, Shah MW, Jiman-Fatani AA, Othman NA, Almasaudi SB, Alawi M, Shakil S, Al-Abdullah N, Ismaeel NA. Genomic and antimicrobial resistance genes diversity in multidrugresistant CTX-M-positive isolates of Escherichia coli at a health care facility in Jeddah. Journal of Infection and Public Health. 2020;13:94100. Doi: 10.1016/j.jiph.2019.06.011

31. Hassuna NA, Khairalla AS, Farahat EM, Hammad AM, Abdel-Fattah M. Molecular characterization of Extended-spectrum $\beta$ lactamaseproducing $E$. coli recovered from community-acquired urinary tract infections in Upper Egypt. Scientific Reports. 2020;10:1-8. Doi: $\underline{10.1038 / \mathrm{s} 41598-020-59772-\mathrm{Z}}$

\section{الكشف عن جين CTX-M في الجراثيم المعوية المنتجة

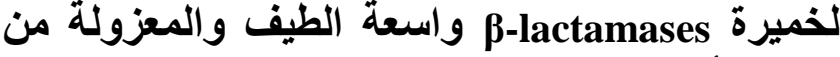 حليب الأبقار}

$$
\text { إحسان منير احمد العراق الأحياء المجهرية، كلية الطب البيطري، جامعة الموصل، الموصل، }
$$

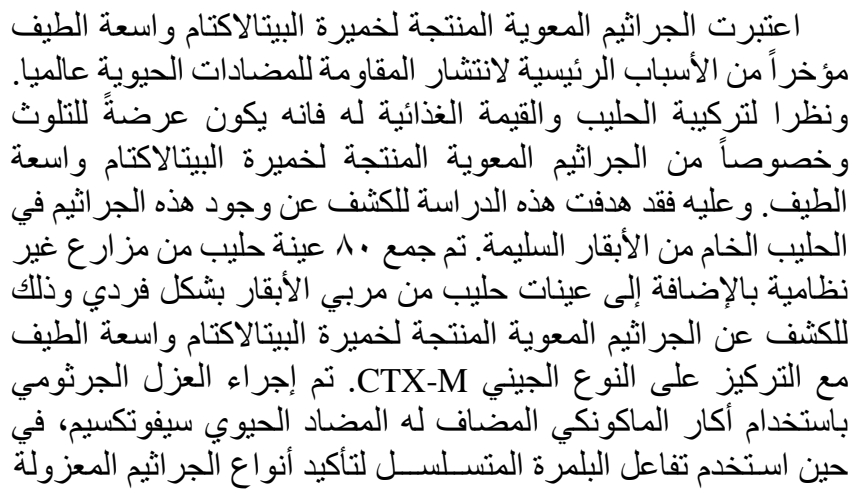




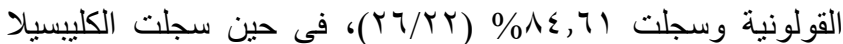

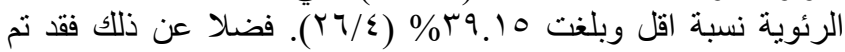
الكثف والتعرف على الجين CTX-M في جميع العزلات المبل الموجبة

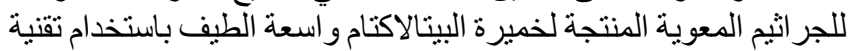
تفاعل البلمرة المتسلسل والذي شمل عزلات الإليثة الإيثيركيا القولونية

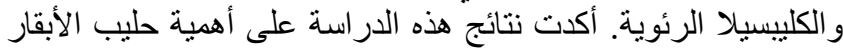

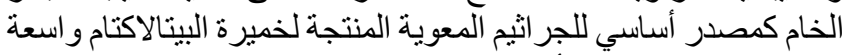
الطيف والتي من المكن أن تنتقل إلى الإنسان.

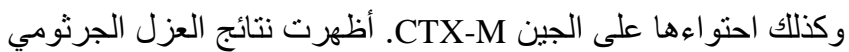

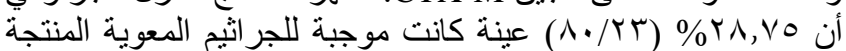

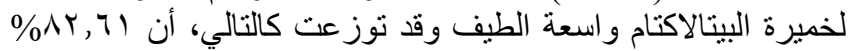

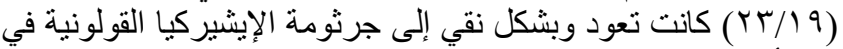

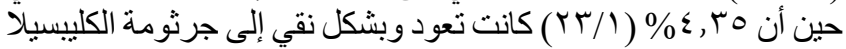

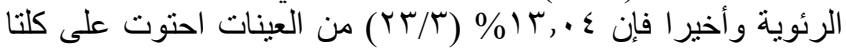

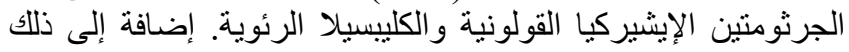

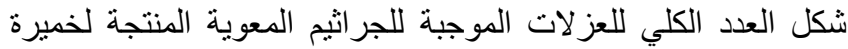
البيتالاكتام و اسعة الطيف جr عزلة لة كانت اغلبها تعود لجر اثيم الإيثيركيا 